KEYWORDS

Economic crisis

Economic growth

Environmental degradation

Natural resources

Commodities

Commodity prices

Inflation

Wealth

Income distribution

Ramón López

Professor of Economics,

Department of Agricultural and

Resource Economics,

University of Maryland at College

Park, Maryland, USA

- rlopez@arec.umd.edu

CEPAL REVIEW 102 - DECEMBER 2010

\section{Global economic crises, environmental-resource scarcity and wealth concentration}

\author{
Ramón López
}

$\mathrm{T}$

hree new structural factors underlie the most recent global crisis:

(i) the fact that several high-population countries have joined the growth process; (ii) the increasing scarcity of environmental and certain natural resources; and (iii) the extraordinary concentration of income and wealth that has occurred in the advanced economies over the last two decades. These structural changes have significantly strengthened the links between global growth and commodity demand; they have made world commodity supply increasingly inelastic, and have rendered economic growth more dependent on easy monetary and financial policies. The combination of these factors could make the world economy highly crisis-prone and may hinder recovery from the current one. 


\section{I}

\section{Introduction}

This article focuses on new structural factors that have played an important but often neglected role in the genesis of the current global crisis, and may also have profound implications for long-term economic growth. It examines the synergetic interactions that exist between three structural factors: (i) the awakening of heavily populated countries, such as China and India, from centuries of economic lethargy, and their emergence as world growth leaders, and as largescale providers of industrial goods and consumers of commodities; (ii) the increasing scarcity of environmental and certain natural resources which, for the first time ever, is starting to be felt in rich and poor countries alike; (iii) the dramatic concentration of wealth that has occurred over the last two decades especially in the advanced economies.

Structural factors (i) and (ii) have made commodity prices highly responsive to economic growth. The increased economic weight of population giants that are still at an early stage of development, such as China, India and others, has increased the commodityand energy-intensity of global economic growth, as growth in these countries is largely based on a rapid expansion of commodity- and energy-intensive industries (Farrell and Grant, 2005). Moreover, while the advanced economies have largely dematerialized their production by focusing more and more on services and knowledge-intensive industries, their consumption has not dematerialized by nearly as much. This asymmetry has meant that the advanced countries increasingly rely on the rest of the world to meet their growing net demand for material goods, energy and other commodities.

As a result of the second factor - the increasing worldwide scarcity of natural resources - the response capacity of commodity supply is becoming less and less flexible, at a time when world growth is fuelling higher commodity demand. As a result, rapid world economic growth is now closely accompanied by rising commodity prices.

$\square$ Research assistance was provided by Asif Islam and Amparo Palacios, graduate students at the University of Maryland at College Park.
Central banks respond to these prices hikes by tightening monetary policy to prevent the corresponding pressures being validated in higher inflation indices, while hopefully still leaving some room for the economy to continue growing, albeit perhaps at a more modest pace. Nonetheless, for reasons to be made clear below, the third structural factor - the increasing concentration of wealt - has made the real economy much more sensitive to tight monetary and financial policies than in the past, and this has considerably reduced the space available for continued economic growth in periods of tight monetary policy.

Over the last two decades, the concentration of wealth in advanced economies, and in many middle-income countries too, has gone hand-in-hand with stagnation among the middle class; and both phenomena are at least partly the result of new policies implemented in this period (Krugman, 2006). This suffocation of the middle class - what Paul Krugman has dubbed "the great wealth transfer"- has made the vast majority of households increasingly reliant on new borrowing to finance their consumption, thereby causing debt-to-income ratios to explode (Taylor and others, 2008). As a large portion of that debt is often subject to periodic interest-rate adjustments, household disposable income (after debt service) has become much more sensitive to interest-rate hikes. Moreover, as global economic expansion depends heavily on rapid consumption growth, especially in the United States and other advanced countries, this has made economic growth ever more reliant on easier monetary and financial policies in those countries. Such policies are essential to allow consumers easy access to credit and support a relatively low debtservice burden despite their higher household debt/ income ratios. As result, middle-class households were for long able to increase their consumption, financed by higher debt levels, even though their real income were being squeezed or remained flat.

In the United States, the share of total household income received by the richest $10 \%$ of households grew continuously from about $35 \%$ in the 1980 s to $50 \%$ in 2007, its highest level ever (Saez, 2009). Ominously, the only other period in the last century in which the wealthiest $10 \%$ received close to $50 \%$ of total income 
was in the years leading up to the Great Depression. In fact, in 1917-28 the share of the top 10\% grew almost exactly as fast as in 1996-2007, rising from $40 \%$ to $49 \%$ in the earlier period and from $40 \%$ to $50 \%$ in the latter (Picketty and Saez, 2003). Apparently, this is more than mere coincidence; when income concentration reaches such extreme levels it makes economies that depend on domestic demand increasingly vulnerable to deep and prolonged crises, because it becomes increasingly difficult to keep demand growing. While domestic income concentration may not directly make economies where growth is primarily export-led, such as those of Latin America, more crisis-prone, it certainly does in countries such as the United States that rely on domestic demand. Moreover, as this and a number of other rich countries provide a large proportion of the rest of the world's markets, a demand slump in these countries could easily drag the world into recession. ${ }^{1}$

As shown below, the greater sensitivity of commodity prices to world economic growth, combined with the greater reliance of economic growth on

1 In most countries with open markets, such as those of Latin America, China, India and many others, wealth concentration may not be a direct obstacle, since economic growth is mostly fuelled by foreign demand. This causes a social "tragedy of the commons" type of syndrome: governments that tend to be driven almost exclusively by gdp growth-maximization objectives have no incentive to prevent a concentration of wealth, since this will not affect an individual country's growth potential. Nonetheless, if most countries in a globalized world apply the same pro-growth policies with no concern for the distribution of wealth, wealth concentration will become contagious across the world. This, in turn, restricts global demand and thus provides a precarious foundation for sustained global economic growth. loose monetary policies in the advanced countries, are likely to make rapid economic growth with price stability much harder to sustain in the future; and they may make it more difficult to recover from the current crisis.

Section II of this article makes a detailed analysis of the emergence of the recent great recession, against the backdrop of a new economic order generated by the three structural factors mentioned above. The analysis starts by reviewing interactions between rich and poor countries, highlighting how the economic success achieved by many highly populated but historically poor countries has made global economic growth more widespread. Section III reviews environmental aspects and their relevance for global economic growth. Section IV considers the consequences of the radical new policies implemented by various conservative governments, based on the intellectual laissez-faire ideology reinvented in the advanced economies, to which many middle-income countries around the world have signed up. One result of these policies was greater concentration of wealth in most countries (Jerzmanowski and Nabar, 2008; Philippon and Reshef, 2009). Thus, while economic growth across countries has become more inclusive, with the growth club expanding to encompass a number of previously excluded countries, income growth within individual economies has increasingly become the privilege of a relatively small minority. Section $\mathrm{V}$ describes the relationship between energy and raw materials prices, inflation, and the outbreak of the crisis. Lastly, section VI concludes by showing how the unusual nature and intensity of the current crisis have been the corollary to these developments.

\section{II}

\section{The new economic order: retrospect}

\section{The dematerialization of production in the North}

For much of the twentieth century, continuous economic growth was the privilege of an exclusive club comprising no more than a fifth of the world's population (henceforth referred to as the "North"). As the North grew ever richer, it underwent continuous structural change, and its production became increasingly "dematerialized” (López and Stocking, 2009). The structure of gross domestic product (GDP) in the North became increasingly focused on services and, generally, on human-capital- and knowledgedependent activities. As a counterpart, the totaloutput share of natural-resource-based activities, and later most manufacturing sectors, gradually shrank. Figure 1 illustrates the intensity of this process over the last 50 years in the United States, as the shares 
of both commodity production and manufacturing in total GDP have steadily declined. Manufacturing, agriculture, forestry, fishing, oil extraction and mining have seen their combined GDP share plummet from over $40 \%$ in the early 1950 s to less than $20 \%$ in the early 2000 s.

This dematerialization of the North's production has not been matched by a similar dematerialization of consumption. While there was some shift in the structure of consumption - which ceased to be centred on commodities such as foodstuffs- consumers in the North continued to expand their demand for energy and industrial products, especially durable goods, at a rate that often outpaced their per capita income (Ghertner and Fripp, 2007). The North's consumption dematerialized much more slowly than its domestic production, making it increasingly reliant on the rest of the world (the "South") to supply, firstly, commodities (including energy and other raw materials), and then manufacturing goods too, particularly over the last three decades.

An analysis of trade flows in the United States, for example, shows a rapid increase in net imports of commodities and industrial goods as a proportion of that country's total imports and GDP. Figure 2 illustrates this, showing a steep rise in the share of industrial goods in total imports and large increases in imports of manufactured and other industrial goods as a proportion of domestic production. The same is true for most other commodities including metals (see figure 3). Imports of industrial goods and commodities have grown particularly fast over the last two decades.

\section{The roles played by the South}

This article distinguishes two groups of economies in the South: those that are rich in natural resources (most of Latin America, Sub-Saharan Africa and parts of Asia); and those that are labour-abundant (nearly all Asian countries). The labour-abundant South includes population giants such as China and India and a few others, which are home to a very large proportion of the world's total population; in contrast, the resource-rich part of the South is relatively sparsely populated. While there have been periods in which the South as a whole has been able to achieve modest growth, until the last three or four decades few countries in the South had been unable to sustain growth for lengthy periods of time. The resource-rich South essentially became a passive supplier of energy and other commodities to the North.

Since colonial times the North has maintained efficient commodity-producing enclaves in the resource-rich part of the South, selling almost exclusively to northern markets. Burgeoning demand

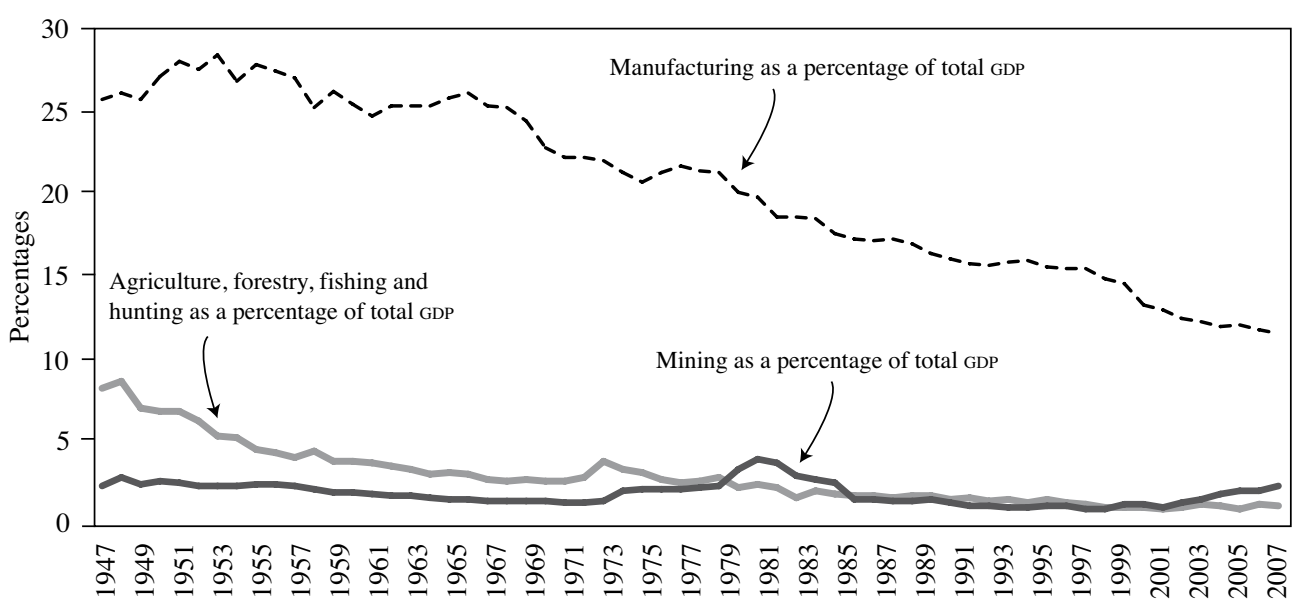

Source: United States Bureau of Economic Analysis.

GDP: Gross domestic product. 
FIGURE 2

United States: share of industrial imports in total imports and GDP, ${ }^{a}$ 1972-2008 (Percentages)

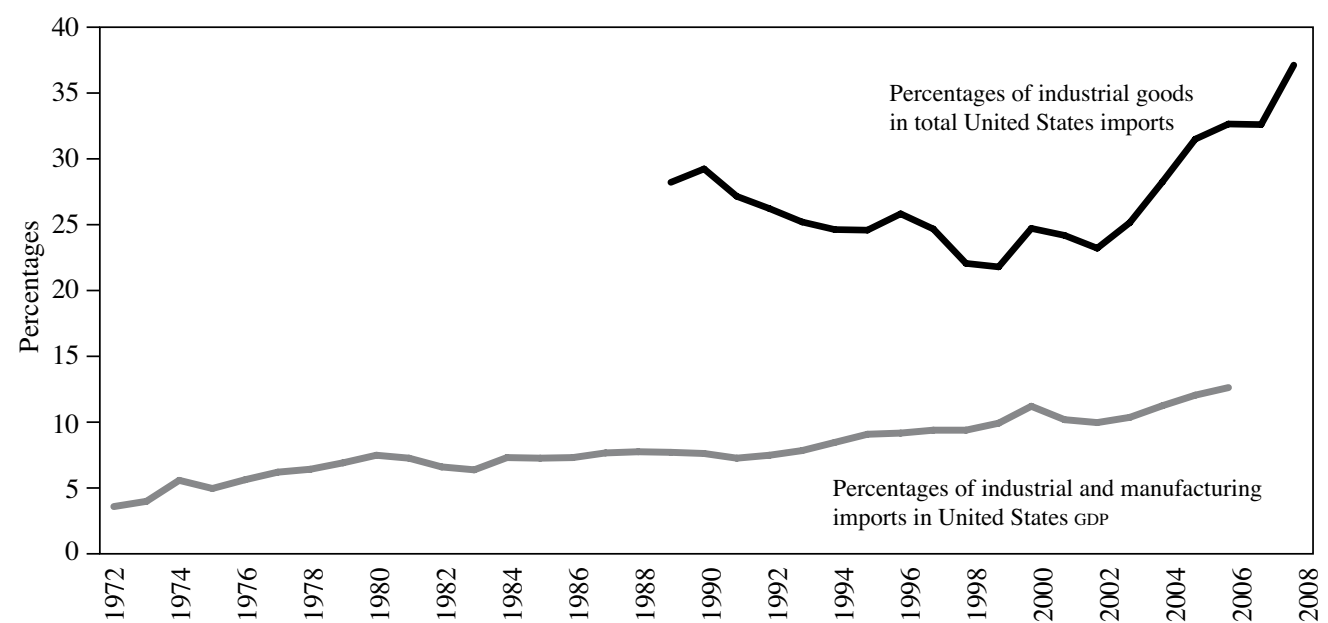

Source: United States Bureau of Economic Analysis; R.C. Feenstra, J. Romalis and P. Schott, "United States imports, exports and tariff data, 1989-2001”, NBER Working Paper, No. 9387, Cambridge, Massachusetts, National Bureau of Economic Research, 2001), http://www.internationaldata.org/.

a The categories are: fuel and lubricants, paper and paper base stocks, materials associated with non-durables, selected construction materials, unfinished and finished metals associated with durable goods, non-metals associated with durables.

GDP: Gross domestic product.

FIGURE 3

United States: Metal imports as a proportion of domestic production, 1900-2004 (Percentages)

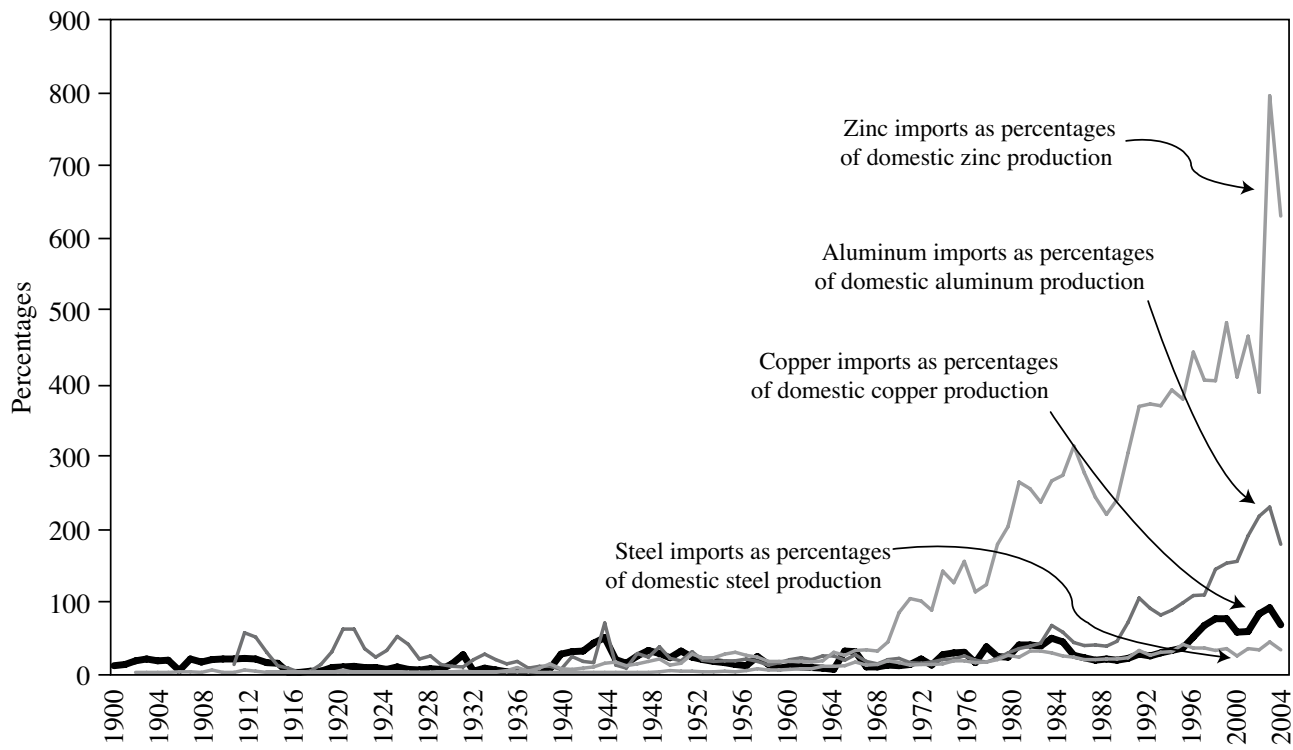

Source: United States Geological Survey. 
for commodities in these markets was matched by continuous exploration and new investments made by the North to expand these enclave economies. The presence of abundant resources in the South and the absence of effective regulations limiting the environmental damage caused by their extraction, together with continuous Northern investments in resource extraction in the (resource-rich) South, kept the global commodity supply curve relatively flat for a long time (in other words, supply was highly elastic), which helped to keep real commodity prices constant (López and Stocking, 2009). As has been documented in several studies, productive enclaves of this type have had few linkages with the rest of the South's economies, and generally contributed little to their growth (de Janvry, 1975).

Both the resource-rich and the labour-abundant segments of the South remained essentially stagnant, exerting little pressure on commodity demand; and this, in turn, helped to keep commodity prices stable. The fact that this process lasted well into the second half of the twentieth century (Sokoloff and Engerman, 2000; Acemoglu, Johnson and Robinson, 2001; Khor, 2000) allowed the North to grow while enjoying the luxury of commodity prices that stayed constant and sometimes even fell in real terms, despite continuously expanding demand from the North throughout much of the century (see figure 4).

\section{The labour-abundant South emerges in the global economy}

As documented by the so-called "resource-curse" literature, the constant expansion of natural resource extraction in enclaves of resource-rich countries of the South has in most cases been insufficient to promote their sustained economic growth (Barbier, 2005). In contrast, the labour-abundant South was better placed to benefit from the growing demand for industrial goods arising from the dematerialization of production in the North, especially over the last three decades.

\section{(a) First, the "Little Giants"}

The labour-abundant South started to shake off its lethargy in the 1970s with the emergence of a few relatively small countries in South East Asia (Korea, Taiwan, Hong-Kong (Special Administrative Region of China), Singapore and a number of others), which succeeded in maintaining rapid growth over long periods

FIGURE 4

Real commodity price trends: producer price index (PPI), ${ }^{a}$ all commodities, 1913-2007

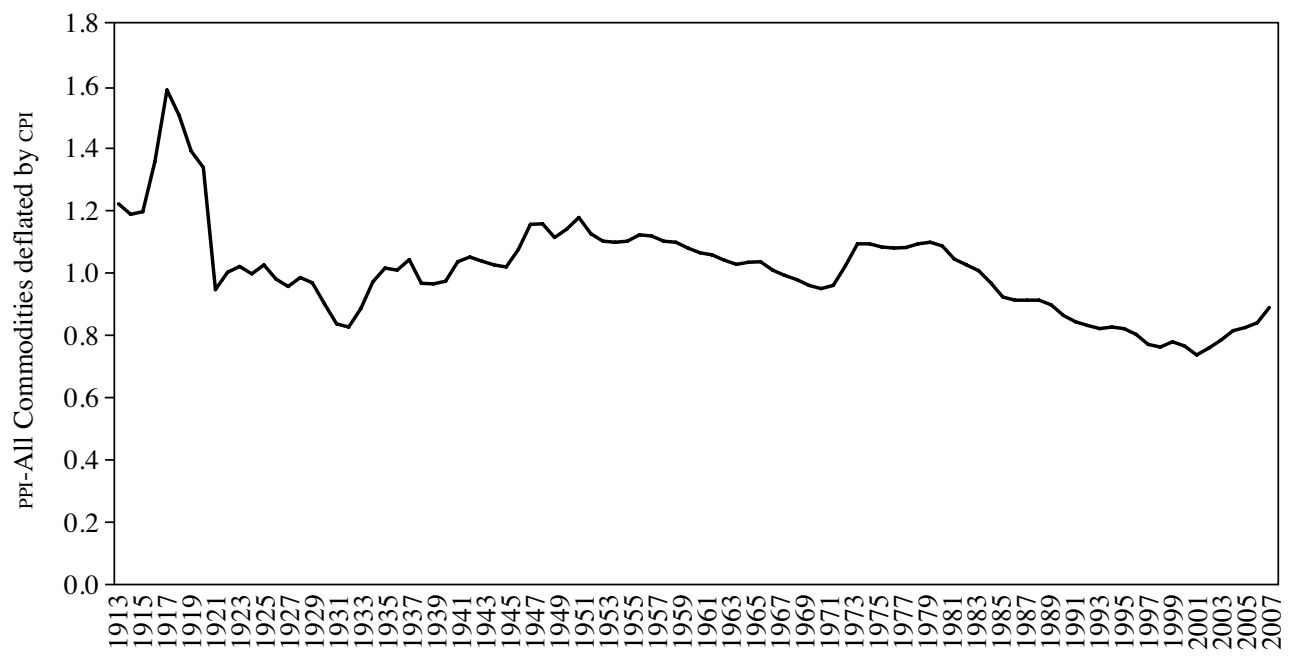

Source: United States Bureau of Labor Statistics.

a Producer price index for commodities as defined by the United States Bureau of Labor Statistics.

CPI: Consumer price index. 
of time, driven by manufacturing exports. Although small in size, these newly industrializing countries (NICs) became major exporters of manufactured goods to the North. The emergence of these little manufacturing-export giants allowed the North to intensify its relative specialization in environmentally clean non-material products, while relying increasingly on the NICs as efficient suppliers of industrial goods to satisfy growing demand among consumers in the North (Krugman, 1994; Lall and Albaladejo, 2004; Noland, 1997).

Although population density in the NICs was high, their overall population was too small to have a significant impact on global demand for commodities, despite their rapid growth. This meant that NIC expansion did not exert greater demand pressure on world commodity prices, which, as shown in figure 4, remained broadly stable during the NIC boom period in the 1970s and 1980s.

Thus, by the late 1980s the world had achieved a remarkable equilibrium: the North plus a few NICs achieved rapid growth - the North on the basis of environmentally clean service-oriented production which greatly facilitated its low-cost, ecologically "sustainable" development; while the NICs supplied the North with an increasing portion of its growing net demand for industrial goods at low market prices, albeit produced at high domestic environmental cost; whereas the still slow-growing resource-rich part of the South supplied raw materials, also at low prices but at the cost of a continuous erosion of its natural resources and environment. ${ }^{2}$

\section{(b) Then, the "Real Giants"}

The late 1980s brought even more dramatic changes, as other large labour-abundant countries of the South implemented major pro-growth policy reforms. The emergence of the new industrial giants

2 It is interesting to note that the North started to dramatically reverse its environmental degradation in the mid-1970s, just as the NICs were emerging as suppliers of low-cost goods produced by polluting industries. This process also coincides with the time when most of the modern environmental regulation in the North begun to be implemented. Increasingly stringent environmental regulation in the North may have been rendered politically acceptable precisely because of the emergence of foreign suppliers of goods produced by polluting industries. López (2008) shows that one of the reasons why the North is able to enforce significant environmental regulation at very low cost (estimated at less than $2 \%$ of GDP) is the emergence of the NICs, and later of other large industrial suppliers, which allowed it to shift its production away from most polluting industries. This view is consistent with the econometric evidence provided by Levinson and Taylor (2008).
(NIGs), mainly China, India and a few other large initially poor countries that succeeded in growing very rapidly, was partly a consequence of the drastic policy reforms implemented in those countries. The new policies included pro-market reforms, privatization of State-owned enterprises, export promotion through exchange-rate policies and other incentives, and weak regulation of pollution, which effectively gave a green light to expand manufacturing production with few environmental constraints. The success of these new policies was assured by the burgeoning demand for industrial goods among consumers in the North.

The NIGs were as efficient as the NICs in supplying industrial goods, but on a much larger scale (Bosworth and Collins, 2008; Panagariya, 2006; López, 2008; Lall and Albaladejo, 2004); and industrial-export-led growth has afforded them unprecedented economic growth for over two decades. Growth in these countries was based on the rapid expansion of industrial exports, facilitated by undervalued exchange rates. ${ }^{3}$ This, in turn, meant a huge accumulation of foreign exchange (see figure 5) which was recycled to the North, especially the United Sates and parts of Europe, thus creating large current-account deficits in the respective economies. ${ }^{4}$ Copious financial flows into the North helped keep interest rates low and massively expanded the supply of credit in those countries, while the capital flow from the NIGs and oil-exporting countries to the North fuelled a continuous rise in equity and real-estate prices, which prolonged the economic boom and helped form a financial bubble. This, in turn, further fed the North's huge appetite for industrial imports from the emerging giants.

Another remarkable (temporary) equilibrium was thus created: the massive financial flows from the new giants, created by their industrial-export success, fuelled the boom in the North which, in turn, fed consumer demand for industrial imports and thus reinforced the NIGs' continuous expansion. Real GDP growth rates of China and India over the last two decades have been consistently above $8 \%$ per year, more than three times the rates achieved by the advanced economies

\footnotetext{
3 According to Rodrik (2007), not only have China and India kept their exchange rates undervalued over the last two decades, but the extent of undervaluation has increased steadily during the period. Most of the NICs also based their industrial export take-off on undervalued exchange rates, although, unlike the NIGs, some of them recently have allowed their real exchange rates to become less undervalued - even overvalued at times.

${ }^{4}$ The exceptions were Germany and Japan, both of which are large exporters of technologically advanced goods and services.
} 
FIGURE 5

China and India: foreign exchange reserves, 1990-2008 (Billions of dollars)

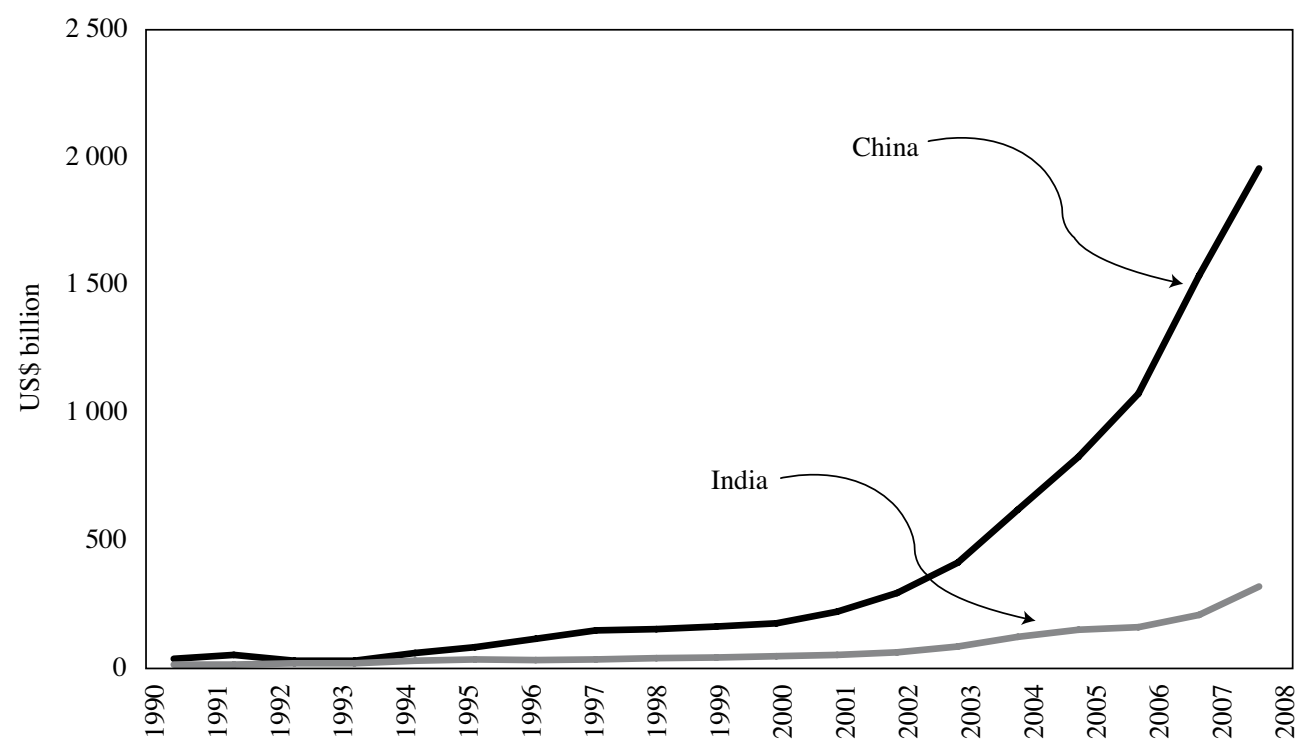

Source: Bank of India and State Administration of Foreign Exchange, People's Republic of China.

(IMF World Economic Outlook). More importantly, the NIGs contributed over US\$ 350 billion per year to global growth in the early 2000 s - that is, over a third of the total annual growth of the world economy, estimated at about US\$ 1.1 trillion. As shown in table 1, the contribution made by China and India, of about US\$ 200 billion, represented nearly $20 \%$ of total annual world growth in the 2000-07 period, compared to just $5 \%$ in the 1980 s.

\section{Finally, commodity-demand pressures}

The new North-NIG boom equilibrium of the second half of the 1990s and early 2000s differed in one important respect from the North-NIC equilibrium of earlier decades: nearly $50 \%$ of all humanity lives in the "new giants", compared to at most $5 \%$ who live in the "little giants". In other words, the emergence of the NIGs dramatically expanded the growth club,

TABLE 1

Distribution of real global GDP growth by region and period

(Millions of dollars)

\begin{tabular}{lrrrr}
\hline Period & China and India & Advanced Economies & Rest of the World & World \\
\hline $1961-1969$ & 5154 & 366333 & 120100 & 491587 \\
$1970-1979$ & 12198 & 514740 & 47150 & 574088 \\
$1980-1989$ & 36740 & 472160 & 94735 & 603635 \\
$1990-1999$ & 86310 & 519200 & 116040 & 721550 \\
$2000-2007$ & 201375 & 618875 & 274525 & 1094775 \\
\hline
\end{tabular}

Source: World Development Indicators, World Bank. 
and, for the first time ever, a large part of the South (most of the labour-abundant portion) became an increasingly important and rapidly growing net consumer of energy, raw materials and other commodities. Constant economic growth ceased to be the exclusive preserve of just a few countries; now, for the first time in history, most the world's population were living in countries that were capable of growing. Only the resource-rich South remained more or less at a standstill.

The NIGs' recent leadership of world economic expansion has made growth much more commodityand energy- intensive than in previous decades, when it was mainly confined to the North. This is a consequence of the large increase in the absolute scale of economic growth caused by the incorporation of $50 \%$ of the world's population, formerly dormant, into the growth process. Moreover, the fact that the massive population of the now expanding NIGs still has a low per capita income means that their incomeelasticity for food, energy and other commodities is much higher than in the advanced economies. In other words, the continuous upward shift of the world commodity demand curve caused by income growth is now occurring much faster than before.

The rapid growth of the NIGs thus generated not only a drastic expansion of the supply of industrial goods but also a dramatic increase in the NIGs' demand for energy, food, and other commodities. As the NIGs started from very low levels of consumption, their increased demand for such commodities initially had little repercussion on world markets. By the mid-1990s, however, they had become significant net importers of commodities, energy, and other raw materials. After more than a decade of annual growth of $8-10 \%$, the huge populations of the NIGs expanded their demand for commodities to account for a sizable portion of total world demand, and so it remains today. Figures 6 and 7 illustrate the rapid rise of consumption levels in China and India and their shares of total world consumption of energy and certain other commodities over the last two decades.

FIGURE 6

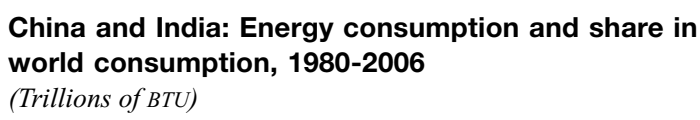

China and India: Energy consumption and share in world consumption, 1980-2006

(Trillions of BTU)

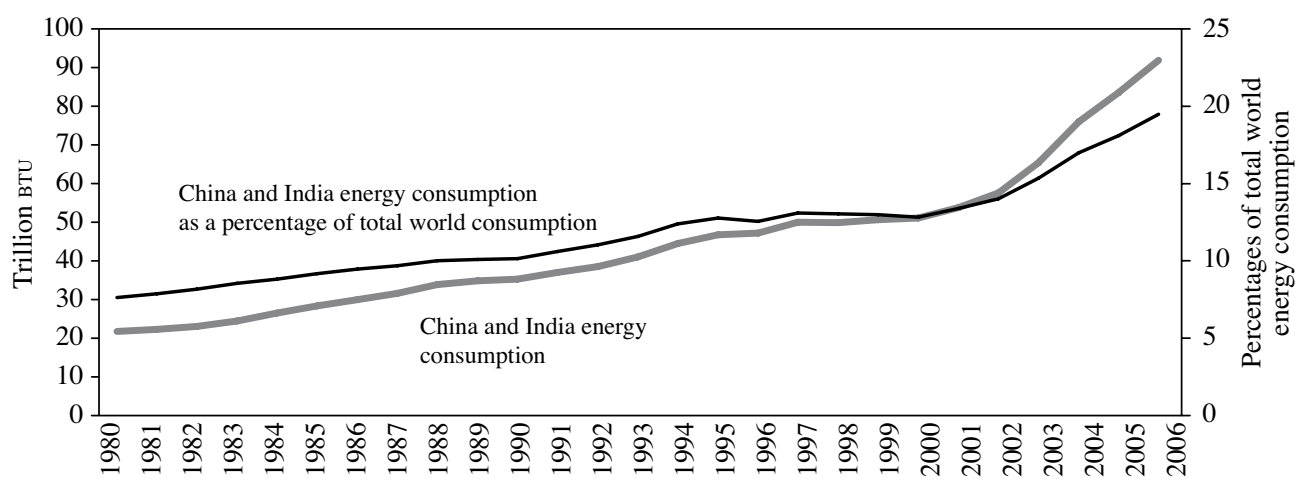

Source: United States Energy Information Administration (EIA).

BTU: British thermal unit (unit of energy). 


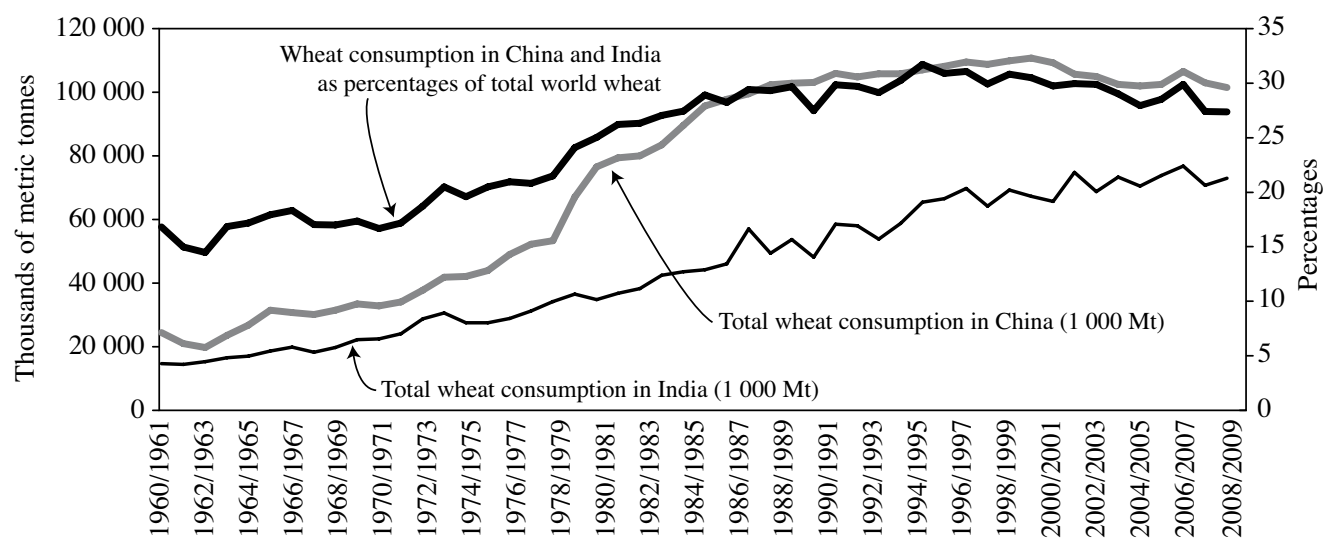

Source: United States Department of Agriculture (USDA).

\section{III}

\section{Environmental-resource scarcity and commodity supply}

As a result of the incorporation of the NIGs into the growth process, the relation between commodity demand and economic growth is becoming ever closer. At the same time, the natural resources that the South used to possess in large quantities, are becoming less abundant, and governments are finally starting to take seriously some of the dire environmental consequences of the frenetic expansion of natural resource extraction. While most underground raw materials may still be plentiful, there are signs that their supply will have to tap increasingly more expensive sources; moreover, resource extraction has led to massive environmental costs affecting extremely valuable ecosystems, water quality, forests and other increasingly scarce environmental assets. ${ }^{5}$

\footnotetext{
5 With some important exceptions, the real limits on commodity supply are not so much the scarcity of in-ground raw materials, but the high and rising environmental costs that their production entails (Simpson, Toman and Ayres, 2005). Resource extraction (mining, oil drilling and other activities) seriously affects water quality, soils and forests (for example, mountain top removal for
}

Under increasing pressure from international nongovernmental organizations (NGOs), local communities that are becoming aware of their ancestral rights over natural resources, and other parts of domestic civil society, governments in the resource-rich South are finally starting to implement policies aimed at limiting some of the large environmental costs that commodity extraction entails. More countries are now enforcing environmental regulations, albeit very timidly, on the use of many ecosystems that tend to be destroyed by unscrupulous resource extraction. ${ }^{6}$ In other words,

coal extraction). The United States could significantly increase its oil production by expanding off-shore or Alaskan production, at the cost of ever higher risk of environmental destruction.

${ }^{6}$ Brazil, for example, has passed an environmental crime act with stiff sanctions including imprisonment; and NGOs frequently lobby for the enforcement of laws to protect the Amazon (Da Motta, 2003). In 1991 Colombia's constitutional law completely reorganized environmental management, resulting in stricter enforcement. Priority has been given to the use of economic instruments, and especially to punitive and compensatory pollution charges or taxes (Huber, Ruitenbeck and da Motta, 1998). More recently, China, Taiwan Province of China, and Korea have implemented 
the countries of the South have started doing what the few natural resource-rich countries in the North (the United States, Australia and Canada) did several decades ago - impose heavy restrictions on resource extraction to mitigate the damage caused to fragile ecosystems and other renewable natural resources. These restrictions ultimately make commodity extraction more costly.

This means that now, perhaps for the first time ever, the long-run supply curve of natural-resourcebased commodities has become relatively inelastic. The finite capacity of the natural world is finally being reflected in an increasingly vertical commodity supply curve. Ironically this is due not so much to the scarcity of non-renewable underground materials but mainly to the increasing degradation of ecosystems and other renewable natural resources that are crucial to life, resulting from the massive exploitation of non-renewable resources.

In short, economic growth is now shifting the world commodity demand curve upwards more rapidly at a time when the long-run commodity supply curve has become relatively inelastic. Hence, it appears that world economic growth and commodity prices are now more intimately related than in earlier decades. This may explain the large hike in commodity prices that took place in 2003-2007 and, as shown below, helped trigger the current recession. Since the increased sensitivity of commodity prices to economic growth is symmetric, it also explains the rapid fall in commodity prices in the depths of the crisis and their rapid recovery in the second half of 2009 and 2010, when world economic growth began to stage a tentative recovery.

\section{Climate change}

The capacity of the atmosphere to absorb greenhouse gases without major climatic disturbance is another prominent example of how renewable resources act as a constraint on the expansion of commodity- and raw-materials-based industries. Once environmental policies incorporate the costs of climate change, this will eventually have to be reflected in higher prices for these products. The emergence of the new industrial giants and ever-increasing demand for material goods

policies that are broadly in line with international standards for targeting and reducing greenhouse gases (Shapiro, 2009). Engel and López (2008) provide a detailed account of how organized local communities have recently emerged around the world to uphold their rights and restrict access to natural resources. by consumers in the North have kept greenhousegas emissions at high levels, resulting in increasing concentrations of such gases in the upper atmosphere (Bohringer and Loschel, 2003; Loschel and Zhang, 2002). At the same time, the scientific evidence shows that an impending climate disaster can only be avoided if greenhouse-gas emissions are drastically cut. The demands made on the atmosphere have for too long outweighed its capacity for self-renewal, leading to an accumulation of climate-changing gases with the potential to cause major setbacks for human development.

The NIGs are responsible for a growing share of total global emissions, which had surpassed $25 \%$ in 2006 (see figure 8). More importantly, the elasticity of emissions with respect to economic growth in the NIGs is very high, because production in those countries makes intensive use of fossil fuels, including oil, natural gas and coal. This means that continued economic growth in those countries will entail a large increase in their emissions.

Global economic growth is thus even more closely tied to carbon emissions than it was during the late twentieth century; and even merely stabilizing world emissions at their current unsustainable levels will require much more intensive and costly efforts by the North to compensate for increasing emissions from the NIGs. Reducing the magnitude of climate change constitutes a new constraint on economic growth that has been largely ignored over the last few decades. In other words, an important yet hitherto ignored limit to growth in the North has been aggravated by the rise of the NIGs as powerhouses of global economic growth and by the constantly expanding consumption of material goods in the North..

The Kyoto Protocol of the United Nations Framework Convention on Climate Change, originally envisaged as a mechanism to deal with the growing emissions of climate-changing gases, has thus far proven ineffective owing to a lack of commitment by the largest carbon emitters, such as the United States, China, India and other major economies. Notwithstanding the, hitherto mostly failed, attempts to develop an international institution that is effective in limiting carbon emissions, sooner or later the world's economies will have to recognize this constraint; but imposing heavy restrictions on carbon emissions would imply new constraints on the growth of the NIGs and could even threaten their role as large-scale providers of (highly carbon-intensive) industrial goods to the North. 


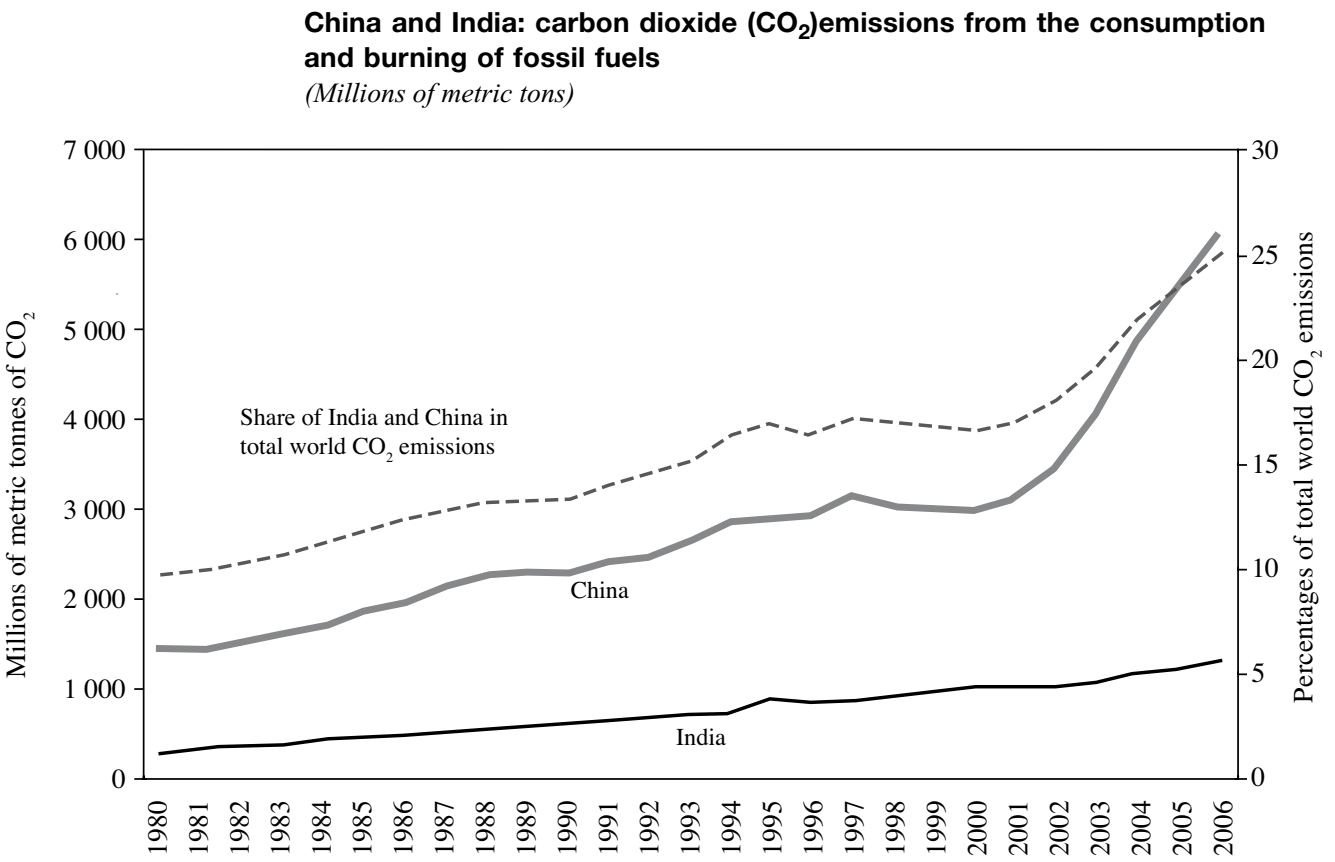

Source: United States Energy Information Administration.

\section{IV}

\section{The new economic policies}

\section{The North "sets its economy free" from the "shackles of government"}

By the early 1980s the North had embarked upon its own "structural-change" process. The view that the "omnipotent state" and excessively high taxes were suffocating the private economy became widely accepted among policy-makers and economists; and the belief was that tackling these issues would make it possible to increase economic efficiency and thus allow for faster economic growth. Most countries in the North embarked on a far-reaching policy experiment that was justified as a means to enhance market incentives for investment and innovation.

The new structural-change policies included several pro-market measures, together with a massive withdrawal of government from the economy. The process included large tax cuts and fiscal retrenchment affecting a broad spectrum of social spending, together with large-scale financial deregulation. Even more important than the financial deregulation, however, was a process of "de-supervision" involving deliberate government actions to weaken the powers of the regulatory agencies by cutting their budgets, staffing, and powers (Caprio, Demirguc-Kunt and Kane, 2008). Moreover, structural change, especially in the United States and other advanced countries, also included policies and legislation (some subtle and others less so) aimed at weakening labour unions; and successive governments allowed the real minimum wage to gradually erode (Autor, Katz, and Kearney, 2006). These policies significantly weakened workers' bargaining power, which ultimately may have led to lower real labour earnings for all except top executives, financial traders and a few others. Although some of these policies may have encouraged investments, especially financial ones, they also appear to have had a number of serious, yet presumably unintended, consequences for wealth distribution.

Against a backdrop of increasing globalization, and in some cases under pressure from international financial institutions (IFIs), these policies in the North 
were imitated by governments in many countries of the South. Indeed the same ideological consensus that led the North to adopt such radical reforms took root among most policy-makers and economists in developing countries. Of course, this extreme ideology of more market and less government (and less taxation) was partly created and supported by institutions directly or indirectly funded by élite groups, including think-tanks, universities and most of the media. The ever greater ideological influence gained by the élites through these institutions has been replicated in many countries in the South and has become their main and most effective lobbying mechanism. This paved the way for IFIs to serve as vehicles for instituting similar policy reforms in developing countries. Policy-makers in developing countries, many of whom had received their academic training in United States universities, did not need much persuasion - particularly since following IFI advice would significantly improve access to international credit and other types of international support.

\section{The state does not regulate... wealth becomes more concentrated}

These policies, which were intended to increase economic efficiency and maintain economic growth in the North, may also have been partly responsible for the massive concentration of income that has occurred over the last two and a half decades. ${ }^{7}$ While

\footnotetext{
7 The rapid conversion of the economies of the North towards services and away from traditional industrial activities was another factor that may have contributed to the erosion of the middle-class and to greater income concentration. A large part of the industrial labour force which had achieved middle-class status lost their jobs and suffered significant income losses over the adjustment period (this is sometimes referred to as the "lost generation"). There are many studies that try to explain the concentration of income by focusing mainly on the distribution of wages among broad groups within the labour force (Autor, Katz and Kearney, 2006; Autor, Levy and Murnane, 2003; Card and di Nardo, 2002). Many of these emphasize the implications for the wage distribution of new technologies and higher levels of human capital. A study by Gordon and Dew-Becker (2007) analyses the consequences for wage polarization of the decreasing unionization of the labour force - a process that has accelerated precisely since the time of structural change. Few studies have analysed the upper end of the wage distribution, in which a high portion of wage incomes seems to have become concentrated. Kaplan and Rauh (2009) do this by showing that the amazing pay increases received by executives of investment banks, hedge fund, private equity and mutual fund managers and traders, as well as other categories of top executives in large corporations, largely explain the observed polarization of wage income. This increase in executive pay, benefiting perhaps no more than $1 \%$ of the labour force, is mainly due to the extreme financial
}

not necessarily the sole cause of growing inequality, the evidence suggests that these policies contributed significantly to the trend (Sloan, 1997). Figures 9 and 10 give an idea of the massive concentration of income that has taken place in the United States and United Kingdom, respectively, especially since the early 1980s. In the United States, the middle class (defined here as the second, third and fourth quintiles of the household income distribution, representing about 200 million people) saw its share of national income shrink continuously from nearly $54 \%$ in 1980 to $47 \%$ in 2006 , while the share of the poor (the lowest 20\%) shrank from 5\% to $4 \%$. Most of these reductions benefited the wealthiest $5 \%$ of the population, whose share of national household income grew from $17 \%$ to $22.5 \%$ over the same period (in 2007 the richest 400 households in the United States, with an average annual income of US\$ 350 million per household, received more than $1.5 \%$ national income). Similarly in the United Kingdom, the share of the middle class fell from $55 \%$ to $50 \%$ between 1980 and 2006, while that of the poorest quintile also dropped from $10 \%$ to $8 \%$. Concomitantly, the share of the top $10 \%$ of households grew from $20 \%$ to $27 \%$ of total household income.

As a result of this concentration of income, the average real household income of the middle class in the United States has hardly increased over the last three decades, rising from US $\$ 48,000$ in the early 1980 s to just US\$ 52,000 in 2007 (see figure 11). In other words, while annual per capita GDP grew by more than $2 \%$ in this period, income growth in middleclass families was about $0.3 \%$ per year. In contrast, the mean real household income of the wealthiest $5 \%$ of the population rose dramatically over the same period, from US $\$ 155,000$ to US $\$ 290,000$, far outpacing per capita GDP.

\section{Dilemmas and paradoxes}

The new regulatory environment provided incentives for business profit that were highly positive for economic expansion. Nonetheless, income concentration made it harder to match those incentives with the expansion of domestic demand needed to sustain such profits and fuel economic growth over time. When income becomes more concentrated, the middle class - the backbone of the consumer economy - is squeezed; and

deregulation and other structural adjustment policies implemented in the early $1908 \mathrm{~s}$ 
FIGURE 9

United States: income distribution: income shares by group, 1967-2005 (Percentages)

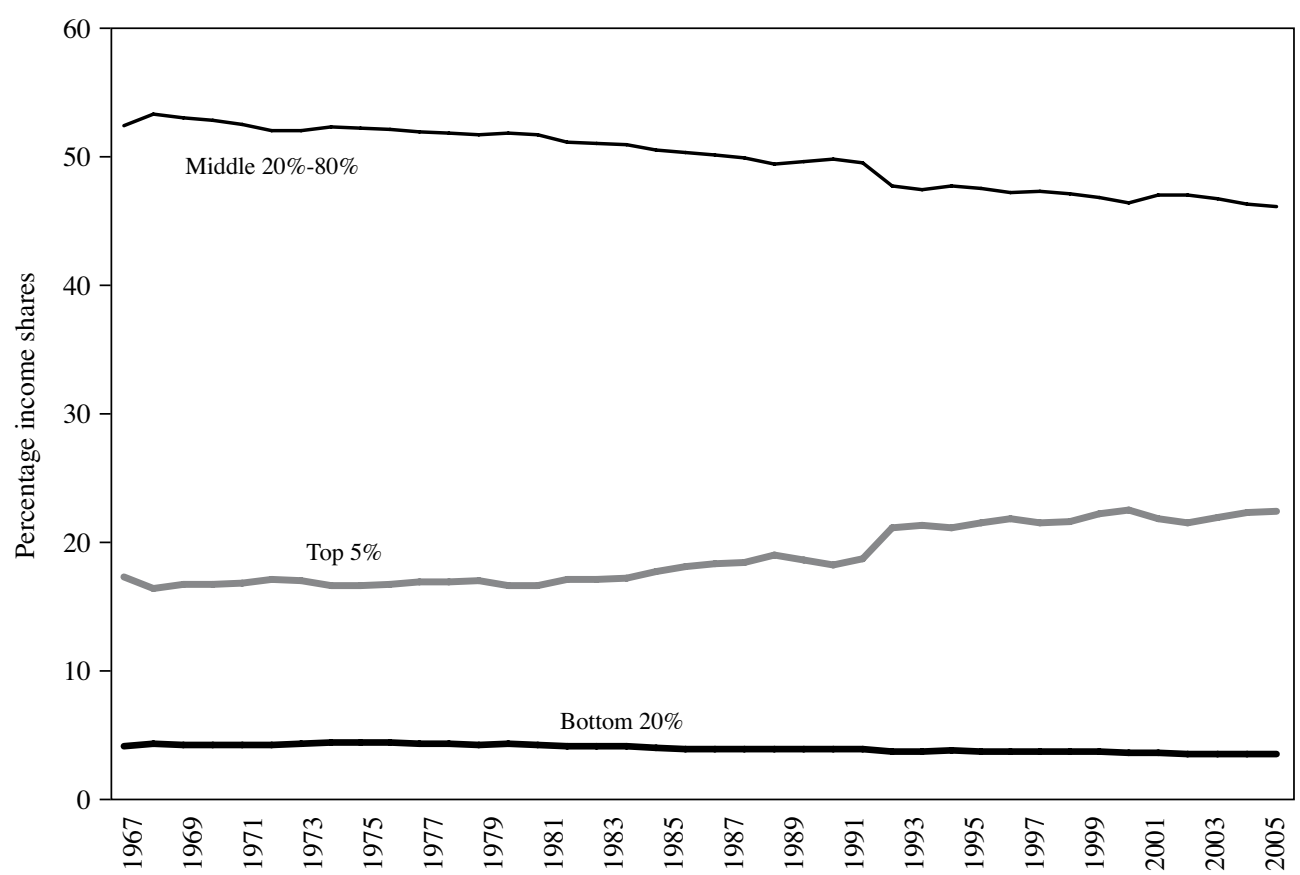

Source: United States Census Bureau.

FIGURE 10

United Kingdom: income distribution: income shares by group, 1961-2001 (Percentages)

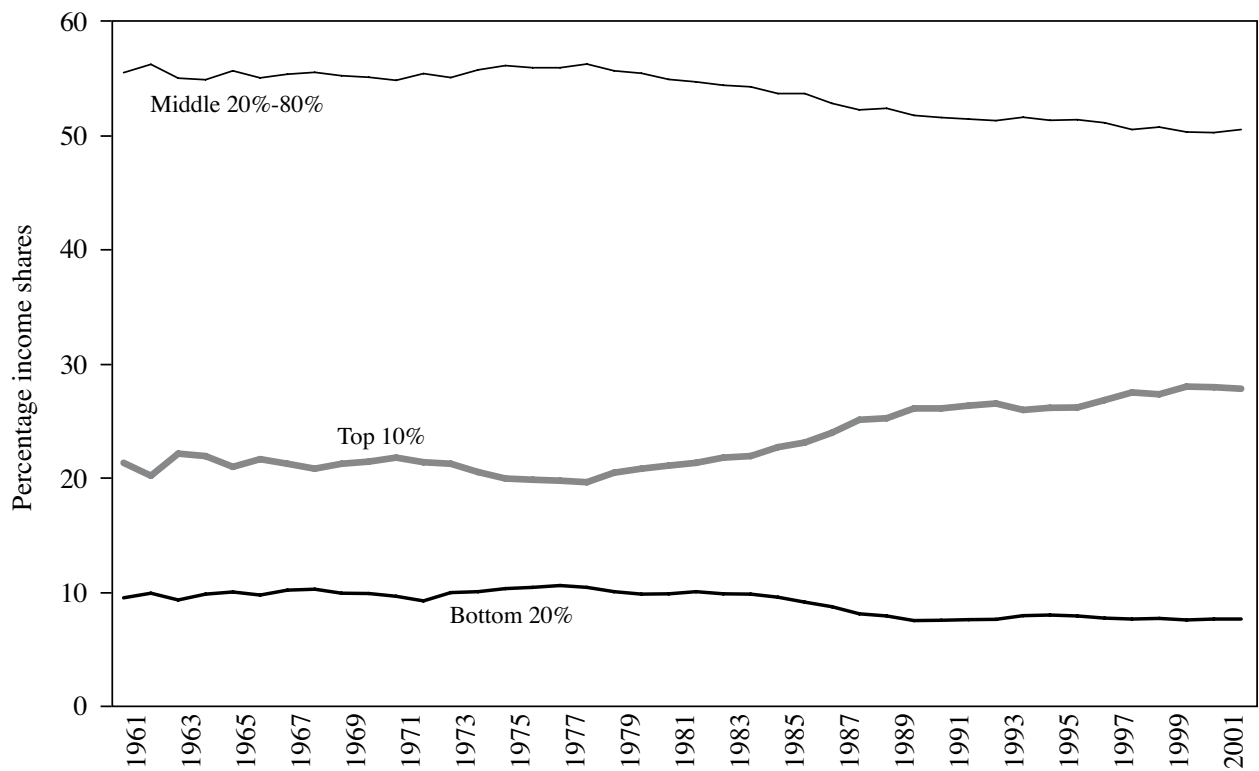

Source: World Income Inequality Database (WIID), United Nations University - World Institute for Development Economics Research (UNU-WIDER). 
United States: real family income, by income group, 1967-2007 (Dollars at 2007 prices)

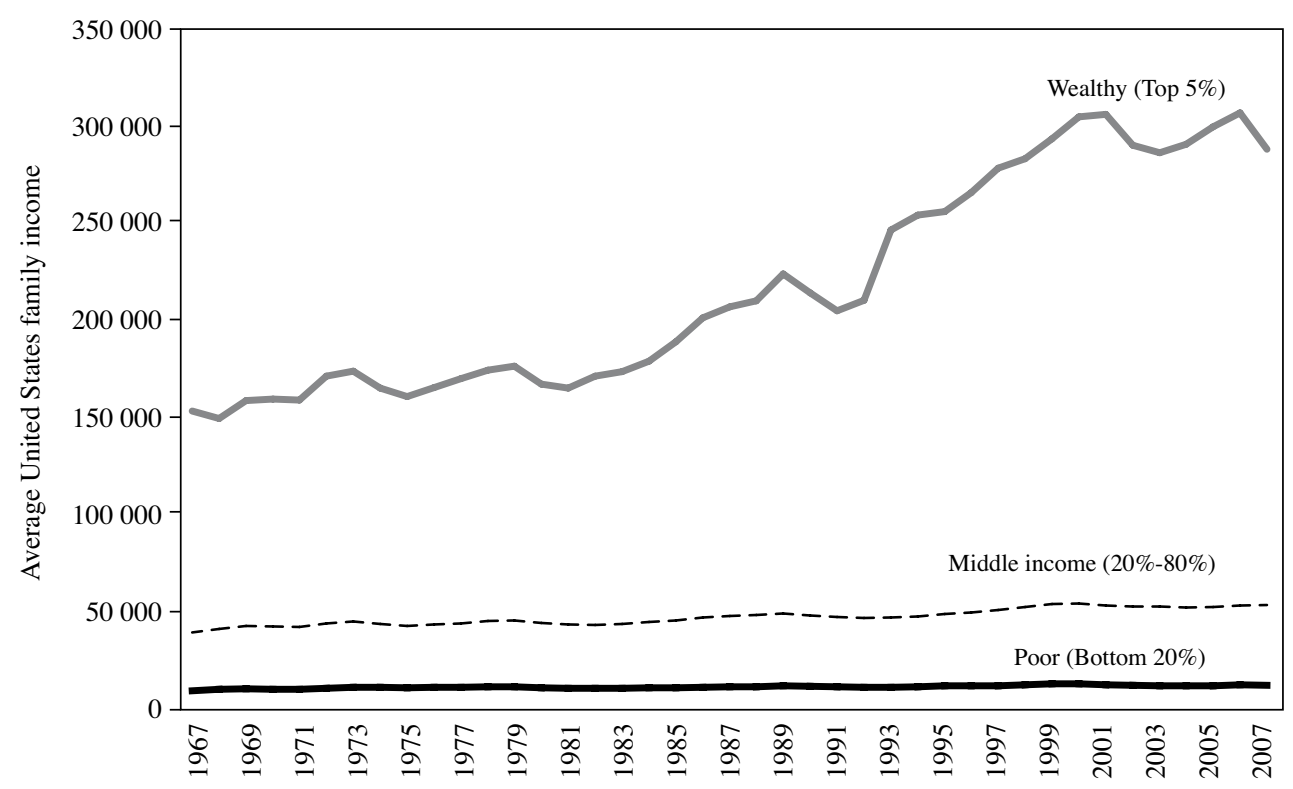

Source: United States Census Bureau.

this makes it much harder to keep domestic demand growing at the rates needed to sustain high rates of business profits and economic growth.

The maintenance of a high rate of economic expansion in the North depends largely on matching rates of consumption growth (Boone, Girouard, and Wanner, 2001; McConnell, Mosser, and PerezQuiros, 1999). ${ }^{8}$ A continuous and rapid expansion of consumption, in turn, needs a prosperous middle class; but middle-class incomes grew by less than one eighth of the per capita GDP growth rate. So, in principle, the rate of growth of middle-class household income was insufficient to support the consumption expansion that the economies of the North needed to sustain their historical growth rates. ${ }^{9}$ The dilemma

\footnotetext{
8 Another possible source of growth was exports, but given the historically low weight of export products in GDP, even rapid export expansion cannot provide enough support to domestic growth. Investment, at less than $20 \%$ of GDP, is also too small to make a significant difference for growth. Moreover, investment is largely driven by consumer demand itself.

9 While the phenomenal increase in the after-tax income of the wealthy meant that their consumption expanded rapidly, the fact that their propensity to consume is far lower than that of the middle class means that the net effect on total consumption of redistributing income from the middle class to the wealthy is, ceteris paribus, negative.
}

was how to persuade the middle class to expand its consumption sufficiently to keep per capita GDP growing by $2-2.5 \%$ per year, when its real income was only growing at $0.3 \%$.

In these conditions, the required consumption growth could only occur if credit was plentiful and cheap, and if the middle class could be induced to accept ever higher debt levels. Why did households fall so readily into the temptation of easy credit? The massive inflow of capital from the NIGs and oil-exporting countries was one contributory factor; and the almost complete financial deregulation and de-supervision by government agencies, which fuelled the proliferation of exotic and highly risky financial instruments, was another. The final ingredient was monetary policy. The Federal Reserve implemented a generally permissive monetary policy in the face of obvious asset-price bubbles; and it also failed in its financial regulation function.

These three factors generated an unprecedented flood of credit and other financial resources into the consumer economy, thereby creating the conditions for the last component of the miracle (or, to be more precise, mirage), namely an extraordinary rise in the price of assets of all kinds, but particularly real-estate and equities, driven by the burgeoning demand for 
such assets that was being fuelled by the massive and continuous inflow of financial resources into the economy. The resulting capital gains made ordinary citizens feel wealthier, even though their income flows were hardly growing at all — since most of the income growth accrued to a very small minority of the population. The confusion between (necessarily) short-term capital gains and higher permanent income induced middle-class families to cut savings and rapidly expand their consumption, financed by easy credit with inflated assets often used as collateral.

Although the dilemma of sustaining economic growth with stagnant middle-class incomes was "resolved" through easy credit and low interest rates, there were ominous implications. This growth model requires ever-rising household debt levels, backed by ever-increasing equity and real-estate prices. The debt burden of the average household almost tripled in two decades, from $45 \%$ of its annual income in the mid-1980s to $120 \%$ in 2004 (Taylor and others, 2008). Obviously this could not be considered a permanent solution.

\section{The monetary and financial regulation syndrome: "kicking the can down the road"}

Almost two decades of monetary and financial profligacy, driven by increasing income concentration, created the conditions for a potential economic tsunami. The middle class' continuing and ever-greater reliance on new borrowing to finance a large proportion of its consumption, made the consequences of restricting monetary policy and tightening financial regulation much more costly than previously. In fact, for every percentage-point hike in interest rates, median household income, after debt service, falls nearly three times as fast when the debt/income ratio is 1.2 , as it is today, than when it is 0.45 as it was in the early 1980s. Moreover, with middle-class income growing so slowly, consumption growth depends almost exclusively on new borrowing. Hence, monetary tightening, or stricter enforcement of financial regulations to curtail the manifestly risky practices of the financial sector, have much more depressing effects on consumption. Consequently, the effects of financial and monetary tightening on the real economy are likely to be much more pronounced than previously, when household consumption was more closely linked to permanent income than to new borrowing.

Awareness of the serious consequences of tightening monetary and financial policies in a heavily indebted economy makes the monetary and financial authorities more reluctant to respond promptly to monetary and financial imbalances; and it may make them less likely to implement effective regulations even when there are clear signs of serious financial "anomalies", such as prolonged asset bubbles. This has helped generate a serious regulatory syndrome, namely addiction. The longer the implementation of corrective monetary and financial measures is delayed, the greater are the short-run adjustment costs of doing so, and hence the greater the incentives for policy-makers to "kick the can down the road" to gain time and leave the financial and monetary authorities of the future to solve the problem. This makes the monetary and financial authorities progressively more complacent, which fosters even deeper imbalances which, by the time the authorities are finally forced to adopt the necessary measures, could potentially trigger a much more serious crisis.

\section{V}

\section{Commodity prices and inflation: the crisis}

Given the relatively small weight of commodities in consumer demand in the North, the sharp commodityprice hikes associated with the rapid growth of the world economy initially had little impact on inflation in the North. Nonetheless, the magnitude of the commodity-demand implied by $8-10 \%$ annual growth rates in the NIGs forced their prices relentlessly upwards (Bosworth and Collins, 2008). As commodity prices skyrocketed in 2003-2007 they started to have an effect on the overall consumer price index (CPI) in the United States and many other countries, which were not always immediately internalized by the monetary authorities provided they did not affect so-called "core" inflation. However, core inflation was eventually affected, and by the end of 2004 the CPI had more than doubled. This ultimately forced the Federal Reserve to belatedly tighten monetary policy, causing a steady rise in the effective Federal 
Funds Rate from $1.25 \%$ in the last quarter of 2004 to over $5 \%$ by the end of 2007 (see figure 12).

As economic growth had become so dependent on ever-expanding household debt and easy credit, which the income-squeezed middle class needed to sustain growth, the monetary tightening of 20052007 had much more traumatic consequences than previous episodes of this type. ${ }^{10}$ In fact, it brought the economic boom to an end and triggered the start of the great global recession. Firstly, the interest-rate hike caused a concomitant rise in mortgage rates, leading to the sudden collapse of the housing market, which - at the peak of a prolonged price bubblewas highly sensitive to mortgage rates. With falling real-estate values and the consequent evaporation of a significant part of earlier capital gains, consumers

10 The financial and real-estate bubble that was fuelled by cheap credit was part of the same phenomenon. suddenly realized that they were not nearly as wealthy as they had been led to believe.

Moreover, the drying up of credit made it increasingly difficult for the middle class to continue borrowing; and, more importantly, the cost to consumers of servicing their accumulated debt went up significantly. The high debt-to-income ratio has made consumer incomes highly vulnerable to interest-rate hikes, possibly more so than ever before. All of this prompted an initial round of adjustment in household consumption and caused widespread defaults in the housing sector, which, in turn, led to financial collapse inflicting capital losses on equity markets. Large-scale capital losses meant the evaporation of the collateral asset values that underpinned continued borrowing, thereby causing a second-round impact on consumption which ultimately allowed the crisis to further impact the real sector, causing high unemployment. This now appears to be inducing a third-round effect on middle-class income and consumption levels, which we are experiencing today. The subsequent collapse

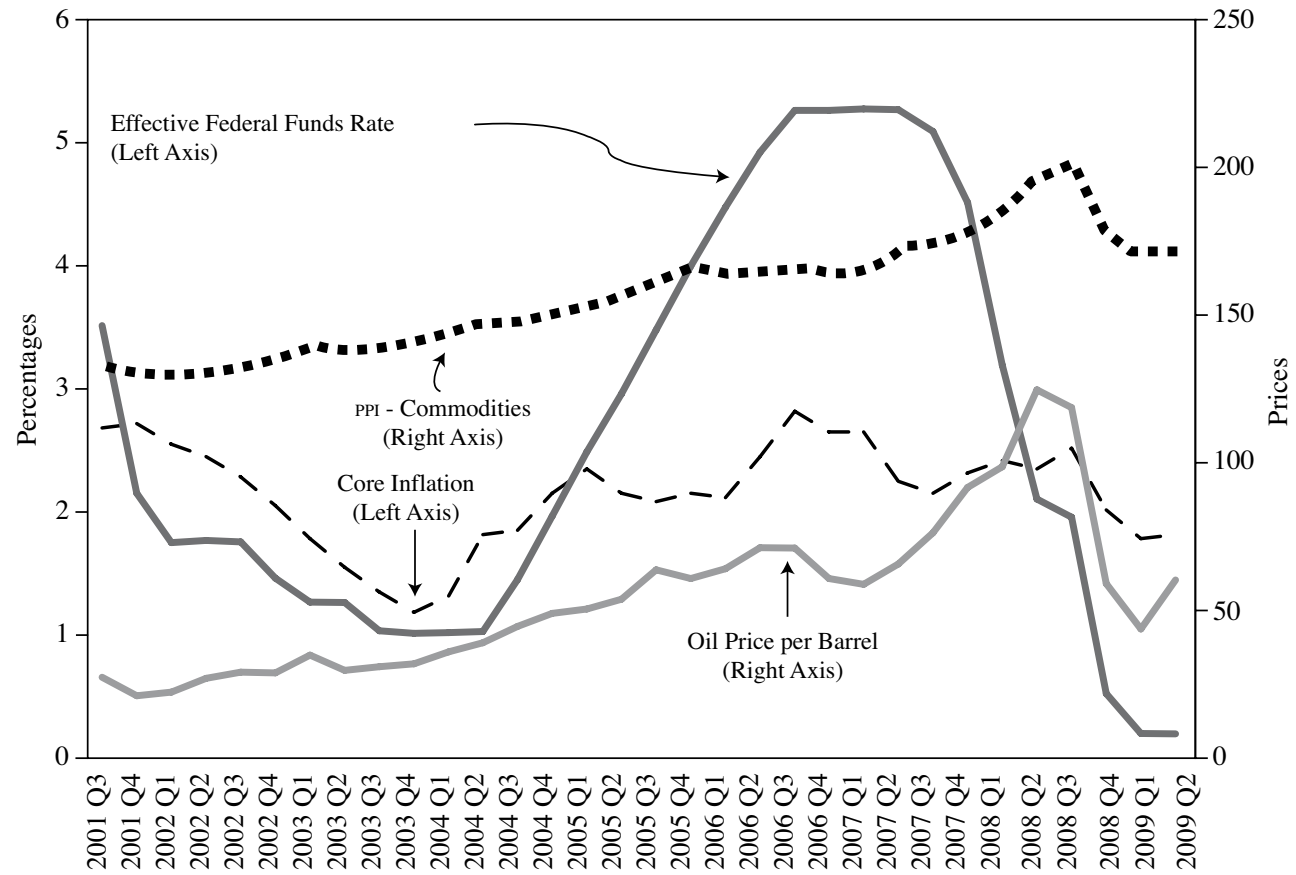

Source: United States Bureau of Labor Statistics, Federal Reserve Bank of St. Louis.

Note: The letter "Q" placed after the year indicates quarter.

PPI: Producer price index. 
of the world economy also led to a steep fall in world commodity demand and prices.

\section{Policy responses to the crisis}

Governments in the North responded to the crisis in the following way: (i) a widespread bail-out process involving massive transfers of State resources to large financial and non-financial corporations; (ii) a drastic relaxation of monetary policy bringing short-term nominal interest rates to near zero levels, together with quantitative monetary easing — whereby the central banks have effectively become direct lenders, in particular buying medium- and long-term government bonds and lending directly to large financial institutions on an unprecedented scale; (iii) massive fiscal expansion that has created deficits seldom seen in the history of the advanced economies.

The new deficit-financed fiscal spending is expected to partly make up for the sharp retrenchment of private expenditure and, in the process, stimulate an economic recovery that may entice consumers once again to revive their pace of consumption. This view sees private consumption being stimulated by the economic recovery generated by the fiscal expansion and by the near-zero interest rates permitted by the more expansionary monetary policy.

Nonetheless, given the obstinate persistence of the new dominant ideology that rejects any structural change that would shift the tax burden towards the wealthy, fiscal deficits effectively imply large new financial liabilities for ordinary citizens, which sooner or later will have to be paid for through higher taxes and/or inflation. In other words, the capital losses suffered by consumers as a result of the real-estate and equity-market collapse, are now compounded

\section{VI}

\section{Conclusion}

The confluence of three major factors has made the world more vulnerable to deep and long-lasting crises, as never before since the Great Depression. One of these factors - extreme income inequality both in advanced and in many developing countries - is as glaring as in the years prior to the 1929 crash. Unlike the 1920s, however, the world is now experiencing an increasing scarcity of environmental resources, by potential new obligations in the future generated by the fiscal deficits and increased public debt. This negative wealth effect is likely to become a serious impediment to any significant revival of private consumption. As a result, the multiplier effect of large but temporary fiscal and monetary stimulus is likely to be small, as impoverished middle-income households will be wary when increasing their spending. Consequently, once the bulk of the various temporary fiscal and monetary stimulus measures are withdrawn, there is a risk that the world economy may slip back into recession.

Moreover, the generous assistance given by governments to financial enterprises and other parts of the large corporate sector effectively means a new large-scale transfer of resources from the average citizen to the wealthiest segments of society. A second "great wealth transfer" may be underway, thus further exacerbating one of the key factors making economic growth vulnerable to deep crises. The fact that little has been done to tighten financial regulation of the major financial companies means that "business as usual" has been resumed in the financial sector. This has resulted in huge profits for that sector and, once again, massive bonuses to top financial executives and traders; while most workers, and the non-financial part of the economy generally, continue to suffer the dramatic consequences of the crisis.

In sum, policy responses to the crisis have been dominated by the prevailing pro-élite ideology. Some of the structural fundamentals that caused the crisis have thus been exacerbated rather than mitigated, which means that the world may remain highly susceptible to massive crises, and recovery from the current one is likely to be protracted and painful for the middle classes.

which is making commodity supply less responsive at a time when the elasticity of the global demand for commodities with respect to world growth has increased. As a result, economic growth is now more closely tied to rising commodity prices than in the twentieth century. The combination of greater wealth inequality and the concomitant impoverishment of the middle class and the high responsiveness of 
commodity prices to global expansion, have potentially lethal economic consequences.

Although inflation in the advanced economies is now less directly affected by commodity prices, the persistent rise in commodity prices fuelled by rapid world growth eventually feeds into core inflation, thereby forcing governments to adopt restrictive monetary policies. As a consequence of the highly concentrated distribution of wealth, monetary and financial tightening now have much more dramatic effects on the real sector of the economy than they used to have. As a result, the world is now more crisisprone, and global economic growth may become much more difficult to sustain than in the past.

In response to the current crisis, the world has seen an unprecedented combination of massive bail-outs for large firms, together with fiscal stimulus measures and extraordinarily lax monetary policies in the advanced countries. Public lending has taken up part of the slack left by the reduced private lending caused by the financial debacle. A new period of easy credit seems to have arrived, with the sole difference that the source is now public rather than private. Moreover, fiscal stimulus has spawned gigantic fiscal deficits, as governments have generally been reluctant to raise taxes on the rich - apart from a few isolated token gestures - to at least partly finance the deficits. While probably preventing the great recession from becoming a new great depression, the anti-crisis policies seem to have done little to address the structural problems discussed in this article. Moreover, the bail-out of large firms may have exacerbated one of those factors by inducing a second-round wealth transfer from the middle class to the super-rich.

The crisis brought about a temporary reduction of commodity prices and a concomitant fall in inflation. Nonetheless, with the structural factors discussed in this paper remaining in place, and given the huge fiscal and monetary imbalances created in confronting the crisis, even the modest recovery of the world economy has revived commodity-demand pressures, and the prices of several commodities have more than doubled over the last eighteen months. If the global economy continues its recovery, commodities may again fuel inflationary pressures, which is likely to prompt governments to reverse monetary policy and reduce fiscal deficits by raising taxes. Furthermore, the large fiscal imbalances mean that any economic recovery would put additional upward pressure on long-term interest rates. Lastly, unless governments are able to divorce themselves from the persistent dominant economic ideology, the necessary future tax increases will almost certainly fall mostly on the middle class, thus exacerbating the third structural factor even further. ${ }^{11}$ The net effect of all this is that the incipient growth recovery is likely to be suffocated.

Restoring sustained economic growth requires addressing the underlying structural factors: make aggregate demand less dependent on easy credit, by reversing the concentration of wealth and income; and promote rapid, environmentally and commodity-saving technological change to make global economic growth less commodity- and environmentally-intensive.

The new policies must start from an understanding that the economic orthodoxy based on the ideology of the élites has failed. Excessive wealth concentration needs to be corrected, to enable the middle-class incomes to expand again. The major threat of looming middle-class tax hikes should be removed by drastically raising taxes on the super rich, the only group that has benefited and continues to benefit from the crisis. The burden of overcoming those huge fiscal imbalances must be borne by the wealthy rather than the middle class - not merely out of fairness but as a prerequisite for sustained economic recovery. Restoring fiscal balance by raising taxes on the highest-income groups would do much to boost confidence among ordinary citizens, enabling them to start expanding consumption again, thus increasing the fiscal and monetary multipliers and paving the way for a more permanent economic recovery.

Would large tax hikes on the super-rich undermine economic growth, as the prevailing ideology would have us believe? The top marginal income tax rate in the United States is currently $35 \%$, compared to $91 \%$ in the 1950 s and early 1960 s, for people earning more than the equivalent of US\$ 2 million per year in 2009 dollars; and it was above $60 \%$ for many years until the early 1980s. Yet this did not prevent the United States economy from growing rapidly in those decades. There are many other examples around the world where extremely high marginal tax rates affecting the super rich have not impeded rapid growth.

Many of the other policies introduced in the 1980 s need to be reversed. The financial sector needs to be tightly regulated, and the so-called "Tobin tax",

11 As this article was being written, the idea of a national sales tax in the USA was gaining increasing support among economists and policy-makers. As is well known, however, such taxes are highly regressive and would inflict yet another blow on the middle class. 
consisting on a small levy on financial transactions should be implemented worldwide. Apart from reducing incentives for unproductive financial speculation, this could provide a major source of tax revenue that could help to correct the alarming fiscal imbalances prevailing in most of the advanced economies.

The advanced countries have made significant progress in controlling the destruction of environmental and natural resources caused by their production systems, thanks to the dematerialization of their production and appropriate environmental regulation. These policies made it possible to internalize many environmental and natural-resource costs generated by the productive sector. Nonetheless, the externalities concept used was too narrow, since it focused only on the domestic environmental effects of economic activity. The fact that much of the natural-resource and environmental destruction taking place worldwide is linked to highly material consumption structures in the developed economies does not seem to bother governments in the North. The North's failure to recognize its consumption as a source of natural resource degradation in the South has exacerbated global commodity shortages. An obvious implication is that consumption needs to be regulated in the North to internalize environmental impacts worldwide and not just the domestic environmental impacts in the North. This would help the South prevent further environmental destruction, which in the long run would make the commodity supply curve even more inelastic.

(Original: English)

\section{Bibliography}

Acemoglu, D., S. Johnson and J.A. Robinson (2001), "The colonial origins of comparative development: an empirical investigation", American Economic Review, vol. 91, No. 5, Nashville, Tennessee, American Economic Association.

Autor, D., L. Katz and M. Kearney (2006), "The polarization of the U.S. labor market", American Economic Review, vol. 96, No. 2, Nashville, Tennessee, American Economic Association.

Autor, D., F. Levy and R.J. Murnane (2003), "The skill content of recent technological change: an empirical exploration", The Quarterly Journal of Economics, vol. 118, No. 4, Cambridge, Massachusetts, The MIT Press.

Barbier, E. (2005), Natural Resources and Economic Development, Cambridge, Cambridge University Press.

Böhringer, C. and A. Löschel (2003), "Market power and hot air in international emissions trading: the impacts of US withdrawal from the Kyoto Protocol", Applied Economics, vol. 35, No. 6, London, Taylor \& Francis.

Boone, L., N. Girouard e I. Wanner (2001), "Financial market liberalisation, wealth and consumption", OECD Economics Department Working Papers, No. 308, Paris, Organisation for Economic Co-operation and Development (OECD).

Bosworth, B. and S.M. Collins (2008), "Accounting for growth: comparing China and India", Journal of Economic Perspectives, vol. 22, No. 1, Nashville, Tennessee, American Economic Association.

Caprio, G., A. Demirguc-Kunt and E. Kane (2008), “The 2007 meltdown in structured securitization: searching for lessons, not scapegoats", Policy Research Working Paper Series, No. 4756, Washington, D.C., World Bank.

Card, D. and J.E. DiNardo (2002), "Skill biased technological change and rising wage inequality: some problems and puzzles", Journal of Labor Economics, vol. 20, No. 4, Chicago, University of Chicago Press.

Da Motta, R.S. (2003), "Determinants of environmental performance in the Brazilian industrial sector", Working
Paper Series, Rio de Janeiro, Institute of Applied Economic Research (IPEA).

De Janvry, A. (1975), "The political economy of rural development in Latin America: an interpretation", American Journal of Agricultural Economics, vol. 57, No. 3, Oxford, Oxford University Press.

Engel, S. and R. López (2008), "Exploiting common resources with capital-intensive technologies: the role of external forces", Environment and Development Economics, vol. 13, Cambridge, Cambridge University Press.

Farrell, D. and A. Grant (2005), "China's looming talent shortage", McKinsey Quarterly, McKinsey \& Company.

Feenstra, R.C., J. Romalis and P. Schott (2001), "U.S. imports, exports and tariff data, 1989-2001", NBER Working Papers, No. 9387, Cambridge, Massachusetts, National Bureau of Economic Research.

Ghertner, D.A. and M. Fripp (2007), "Trading away damage: quantifying environmental leakage through consumptionbased, life-cycle analysis", Ecological Economics, vol. 63, No. 2-3, Amsterdam, Elsevier.

Gordon, R. and I. Dew-Becker (2007), "Selected issues in the rise of income inequality", Brookings Papers on Economic Activity, vol. 38, No. 2, Washington, D.C., The Brookings Institution.

Huber, R.M, J. Ruitenbeek and R.S. da Motta (1998), "Marketbased instruments for environmental policymaking in Latin America and the Caribbean: lessons from 11 countries", World Bank Discussion Paper, No. 381, Washington, D.C., World Bank.

Jerzmanowski, M. and M. Nabar (2008), "Financial Development and Wage Inequality: Theory and Evidence" [online] http://ssrn.com/abstract=1280978

Kaplan, S.N. and J. Rauh (2009), "Wall Street and Main Street: what contributes to the rise in the highest incomes?", Review of Financial Studies, vol. 23, No. 3, Oxford, Oxford University Press. 
Khor, M. (2000), "Globalization and the South: some critical issues", Discussion Paper, No. 147 (UNCTAD/OSG/DP/147), New York, United Nations Conference on Trade and Development (UNCTAD), April.

Krugman, P. (2006), "The great wealth transfer", Rolling Stone, November.

(1994), "The myth of Asia's miracle", Foreign Affairs, vol. 73, No. 6, New York, Council on Foreign Relations.

Lall, S. and M. Albaladejo (2004), "China's competitive performance: a threat to East Asian manufactured exports?", World Development, vol. 32, No. 9, Amsterdam, Elsevier.

Levison, A. and M. Scott Taylor (2008), "Unmasking the pollution haven effect", International Economic Review, vol. 49, No. 1, Philadelphia, University of Pennsylvania/ Osaka University Institute of Social and Economic Research Association.

López, R. (2008), "'Sustainable' economic growth: the ominous potency of structural change", document presented at the Sustainable Resource Use and Dynamics Conference (Switzerland, June 2008), College Park, University of Maryland.

López, R. and A. Stocking (2009), "Bringing growth theory 'down to earth'”, Working Papers, No. 09-01, College Park, University of Maryland.

Löschel, A. and Z. Zhang (2002), "The economic and environmental implications of the US repudiation of the Kyoto Protocol and the subsequent deals in Bonn and Marrakech", Review of World Economics, vol. 138, No. 4, New York, Springer.

McConnell, M.M., P.C. Mosser and G. Perez-Quiros (1999), "A decomposition of the increased stability of GDP growth", Current Issues in Economics and Finance, New York, Federal Reserve Bank of New York.

Noland, M. (1997), "Has Asian export performance been unique?", Journal of International Economics, vol. 43, No. 1-2, Amsterdam, Elsevier.
Panagariya, Arvind (2006), "India and China: trade and foreign investment”, Working Paper, No. 302, Stanford, Stanford Center for International Development.

Philippon, T. and A. Reshef (2009), "Wages and human capital in the US financial industry: 1909-2006", NBER Working Paper, No. 14644, Cambridge, Massachusetts, National Bureau of Economic Research.

Piketty, T. and E. Saez (2003), "Income inequality in the United States, 1913-98", Quarterly Journal of Economics, vol. 118, No. 1, Cambridge, Massachusetts, The MIT Press, February.

Rodrik, D. (2007), The Real Exchange Rate and Economic Growth: Theory and Evidence, Cambridge, Massachusetts, John F. Kennedy School of Government, Harvard University, July.

Saez, E. (2009), Striking it Richer: the Evolution of Top Incomes in the United States (Updated with 2007 estimates), Berkeley, University of California.

Shapiro, M.A. (2009), Environmental Sustainability in East Asia: Policies and Technological Output, document prepared for the APPAM-KDI Conference, Seoul.

Simpson, D.R., M. Toman and R. Ayres (2005), Scarcity and Growth Revisited: Natural Resources and the Environment in the New Millennium, Washington, D.C., Resources for the Future.

Sloan, J. (1997), "The Reagan presidency, growing inequality, and the American dream", Policy Studies Journal, vol. 25, No. 3, New York, John Wiley \& Sons.

Sokoloff, K.L. and S.L. Engerman (2000), "History lessons: institutions, factor endowments, and paths of development in the new world", Journal of Economic Perspectives, vol. 14, No. 3, Nashville, Tennessee, American Economic Association.

Taylor, P. and others (2008), Inside the Middle Class: Bad Times Hit the Good Life, Washington, D.C., Pew Research Center. 